\title{
Response of the Yam Variety Krengle (Dioscorea rotundata) to Organo-mineral Fertilisation at Bouaké in Central of Côte d'Ivoire
}

\author{
Evrard Brice K. Dibi ${ }^{1}$, N'Guessan Kouame ${ }^{2}$, Emmanuel K. N'Goran ${ }^{3}$, Michel A. Kouakou ${ }^{1}$, \\ Jean Marie Y. Kouame ${ }^{2}$, Brice Sidoine Essis ${ }^{1} \&$ Boni N'zue $^{1}$ \\ ${ }^{1}$ Root and Tuber Crops Program, Food Crops Research Station (SRCV), National Centre for Agronomic \\ Research (CNRA), Bouaké, Côte d'Ivoire \\ ${ }^{2}$ Agricultural Production Improvement Laboratory, UFR Agroforestry, Jean Lorougnon GUEDE University, \\ Daloa, Côte d'Ivoire \\ ${ }^{3}$ Coton Program, Coton Research Station (SRCV), National Centre for Agronomic Research (CNRA), Bouake, \\ Côte d'Ivoire \\ Correspondence: N'Guessan Kouame, Agricultural Production Improvement Laboratory, UFR Agroforestry, \\ Jean Lorougnon GUEDE University, P.O. Box 150, Daloa, Côte d'Ivoire. Tel: 225-070-924-0126. E-mail: \\ maximekouamelma@yahoo.fr
}

$\begin{array}{ll}\text { Received: February 11, } 2021 & \text { Accepted: April 27, } 2021 \quad \text { Online Published: May 15, } 2021 \\ \text { doi:10.5539/jas.v13n6p123 } & \text { URL: https://doi.org/10.5539/jas.v13n6p123 }\end{array}$

\begin{abstract}
The decline in yam productivity due to the lack of arable land and impoverished soils forces farmers to use fertiliser. The fertilisers used are mineral, organic or organo-mineral. A study of these fertilisers has been carried out to propose to the farmers a dose or combination that can improve their yield. Thirteen (13) fertilisers obtained from the combination of mineral fertiliser (NPK 15-15-15) and composted cow or poultry manure were tested on the yam variety Krengle in a 3 replicate randomized complete block design. The experiment was conducted over two (2) campaigns at Bouake in Central of Côte d'Ivoire. The results show that high dose mineral fertilisation (NPK 15-15-15, $300 \mathrm{~kg} / \mathrm{ha}$ ) negatively influenced the growth and yield parameters of the yam variety Krengle. High doses of organic fertilisers (Cow manure (CM) 20 t/ha and poultry manure (PM) 20 $\mathrm{t} / \mathrm{ha}$ ) have a positive effect on vegetative growth. While the medium-high doses of organic fertiliser (CM $15 \mathrm{t} / \mathrm{ha}$ and PM $15 \mathrm{t} / \mathrm{ha}$ ) gave better tuber yield (13.5 t/ha) and allowed an increase in tuber yield from 17 to $18 \%$. Organo-mineral fertilisation combining a small dose of organic fertiliser $(5 \mathrm{t} / \mathrm{ha})$ with a medium dose of mineral fertiliser (200 kg/ha) gave also fairly good yield (13.3 and $14.42 \mathrm{t} / \mathrm{ha}$ ) with an increase of 15 to $25 \%$. Thus, 200 $\mathrm{kg} / \mathrm{ha}$ of NPK 15-15-15 associated with $5 \mathrm{t} / \mathrm{ha}$ of poultry or cow manure can be recommended for the cultivation of the yam variety Krengle at Bouake.
\end{abstract}

Keywords: yam variety Krengle, organo-mineral fertilisation, composted manure, growth, yield

\section{Introduction}

Yam (Dioscorea spp.) is a tuber crop grown mainly by smallholders in the tropical and subtropical regions of Africa, the Caribbean, Oceania and South Asia. It is the staple food of more than 300 million people worldwide because of its high nutritional value (Asiedu \& Sartie, 2010; Cornet, 2015; Alabi et al., 2019). Yam plays a very important role in food security and livelihood systems for at least 60 million people in West Africa. It is mainly cultivated in southern Guinea's secondary savannah and savannah (FAO, 1997, 1999; Chukwu \& Ikwelle, 2000). About 67.31 million tonnes of yam (92\% of world production) are produced annually on 7.96 million hectares in West Africa, mainly in five countries, namely Benin, Côte d'Ivoire, Ghana, Nigeria and Togo (Faostat, 2019). Nigeria is the largest producer and alone accounts for about 66 per cent of global production, followed in third place by Côte d'Ivoire, where yam is the largest food crop by volume, with an annual production of about 7.148 million tonnes (Faostat, 2019). It is a financial source for a significant fringe of small-scale producers, especially women, mostly involved in production, processing and marketing (Asiedu, 2003). These qualities make yam a crop of the future for food security and poverty reduction in West Africa (Allogni et al., 2006).

Despite this importance, yam productivity is declining. This decrease is due, as indicated in numerous works (Carsky et al., 1998; Diby et al., 2009, 2012; Hgaza et al., 2012; Cornet et al., 2014; Cornet, 2015) to the low 
fertility of the soil which remains one of the main constraints encountered in traditional culture. Faced with this problem, farmers use fertilisers to increase their production. The fertilisers used are chemical, organic or organo-mineral. Therefore, it is in the interest of the scientific world to propose methods of use and adequate doses to avoid the problem of pollution of agricultural soils in yam culture.

Th is work aims to study the effect of organo-mineral fertilisation on the agronomic parameters of the yam variety Krengle (D. rotundata). Specifically, it involves to:

- evaluate the effect of different amounts of mineral (NPK 15-15-15), organic and organo-mineral fertilisers on the growth parameters of Krengle;

- evaluate the effect of different amounts of mineral (NPK 15-15-15), organic and organo-mineral fertilisers on the yield and dry matter content of Krengle tubers.

\section{Materials and methods}

\subsection{Study Area}

The study was conducted at the Food Crops Research Station (FCRS) of the National Centre for Agronomic Research (CNRA), located in Bouaké, Central Côte d'Ivoire. This city is located at $7^{\circ} 45^{\prime} 00^{\prime \prime}$ and $7^{\circ} 38^{\prime} 00^{\prime \prime}$ latitude N; $5^{\circ} 7^{\prime} 00^{\prime \prime}$ and $4^{\circ} 58^{\prime} 00^{\prime \prime}$ longitude W. It is in the transition zone between the forest climate of the South and the savannah climate of the North (Traoré et al., 2013).

The climate of the study zone is of the humid tropical type with four seasons, including a largely dry season (November to February), a large rainy season (March to June), a short dry season (July to August) and a short rainy season (September to October) (Yesso et al., 1991). These periods have become less and less marked in recent years (Brou et al., 2005). In addition to a high-temperature range $\left(22{ }^{\circ} \mathrm{C}\right.$ in the mornings to $35^{\circ} \mathrm{C}$ in the afternoons), it has constant sunshine and bimodal hygrometry with an annual rainfall of 1,200 $\mathrm{mm}$ (Akassimadou \& Yao-Kouamé, 2014).

The hydrography is mainly composed of the Bandama River and the N'Zi (sub-basin of the river) (Konan, 2017). The vegetation consists of wooded savannah with several species of Poaceae (Séka et al., 2009). The soils are ferrallitic gravelly, moderately saturated, reworked, and shallow and derived from granitic alteration material with a sandy-clay texture (Ettien, 2004).

\subsection{Plant Material}

The plant material used is the long-cycle yam variety Krengle, (D. rotundata). The seeds were obtained by cutting the tubers (Figure 1) into small pieces weighing between 250 and 300 grams.

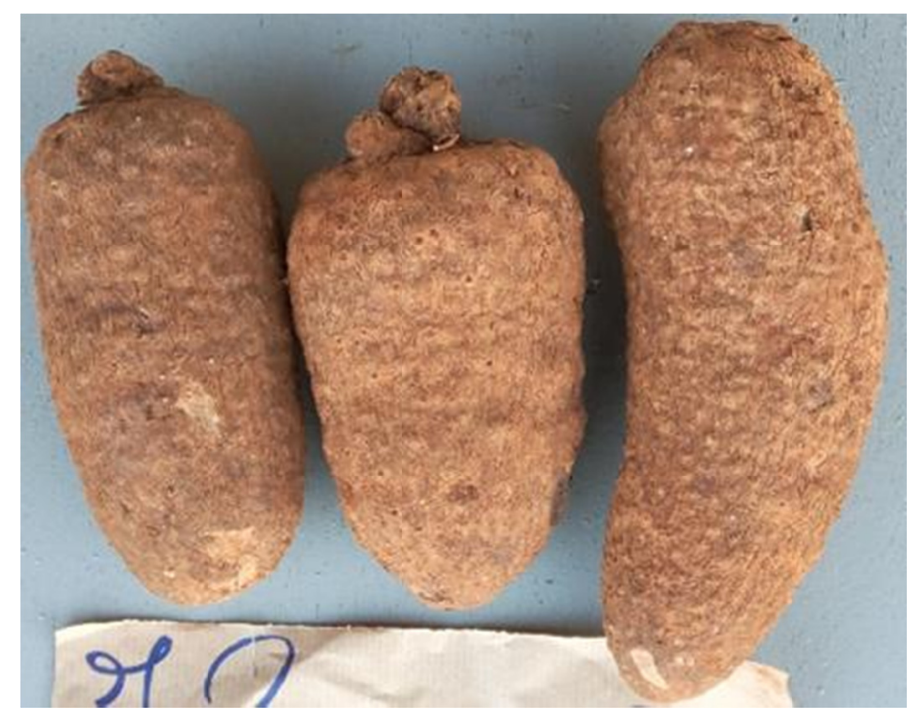

Figure 1. Tubers of the yam variety Krenglè 


\subsection{Morpho-pedological and Physical Characteristics of the Study Site}

The morphological characterisation of the soils intended for the experiment was carried out before setting up the test. The morphological parameters taken into account in this study were: coarse elements, texture, structure, porosity and consistency (Baize \& Jabiol, 1995; Baize, 2004). The characteristics of the two types of soil used for the experiment are presented in Table 1.

Table 1. Morphological and physical characteristics of the soils used for the experiment

\begin{tabular}{|c|c|c|}
\hline Trial years & Year 1 & Year 2 \\
\hline Soil type & Reworked ferrallitic soil (haptic Ferralsol) & $\begin{array}{l}\text { Reworked ferrallitic soil indurated at medium depth } \\
\text { (mesoplinthic haptic Ferralsol) }\end{array}$ \\
\hline Depth (cm) & 150 (no mechanical stress) & 64 (induration stress) \\
\hline Coarse element charge (\%) & 1.31 & 19.55 \\
\hline Texture & Sandy-clayey & Sandy-clayey \\
\hline Apparent density $(\mathrm{Da})$ in $\left(\mathrm{g} / \mathrm{cm}^{3}\right)$ & 0.83 & 1.54 \\
\hline
\end{tabular}

\subsection{Methods}

\subsubsection{Experimental Design}

The experimental device used is a Completely Randomised Block (BCR) with thirteen (13) treatments and three (3) (repetitions) separated from each other by $2.5 \mathrm{~m}$. Each elementary plot contains 35 yam mounds. The planting density was 10,000 mounds per hectare, with a distance of $1 \mathrm{~m}$ between the mounds. The experiment was conducted over two (2) campaigns.

Three types of fertilisers were used for the work, namely:

- Mineral fertiliser (NPK 15-15-15) with four doses: 50, 100, 200, and $300 \mathrm{~kg} / \mathrm{ha}$;

- Composted cow manure, with four doses: 5, 10, 15, and 20 tons/ha;

- Composted poultry manure, with four doses: $5,10,15$, and 20 tons/ha;

The thirteen (13) treatments tested were obtained from the combination of different fertilisers (mineral fertiliser, composted cow manure and composted poultry manure) (Table 2). The control(T0) did not receive any fertiliser.

Table 2. Different combination of fertilisers tested

\begin{tabular}{llll}
\hline Treatments & Fertiliser NPK 15-15-15 (kg/ha) & Composted cow manure(tons/ha) & Composted poultry manure (tons/ha) \\
\hline T0 (NPK 0 + PM 0 + CM 0) & 0 & 0 & 0 \\
T1 (NPK 200 kg/ha) & 200 & 0 & 0 \\
T2 (NPK $300 \mathrm{~kg} / \mathrm{ha})$ & 300 & 0 & 0 \\
T3 (NPK 200 kg/ha + CM 5 t/ha) & 200 & 5 & 0 \\
T4 (NPK 100 kg/ha + CM 10 t/ha) & 100 & 10 & 0 \\
T5 (NPK $50 \mathrm{~kg} / \mathrm{ha}+$ CM 15 t/ha) & 50 & 15 & 0 \\
T6 (NPK 200 kg/ha + PM 5 t/ha) & 200 & 0 & 5 \\
T7 (NPK 100 kg/ha + PM 10 t/ha) & 100 & 0 & 10 \\
T8 (NPK 50 kg/ha + PM 15 t/ha) & 50 & 0 & 15 \\
T9 (CM 20 t/ha) & 0 & 20 & 0 \\
T10 (CM 15 t/ha) & 0 & 15 & 0 \\
T11 (PM 20 t/ha) & 0 & 0 & 20 \\
T12 (PM 15 t/ha) & 0 & 0 & 15 \\
\hline
\end{tabular}

\subsubsection{Implementation of the Experiment}

(1) Establishment and Management

The yams were planted by putting a cutting (a cut piece of tuber) in each mound. The mounds were made by hand using a hoe, and about $0.5 \mathrm{~m}$ and $1 \mathrm{~m}$ in height and diameter. 
The maintenance of the plot consisted of weeding and staking the yams. Weeding was done on demand (each time the plot was grassed) using a hoe. They consisted of pulling out weeds that compete with the yam plants. Staking began 2 to 3 months after planting and mounted the yam stems on previously produced stakes. One stake was provided for four mounds.

(2) Composting and Fertilisation of the Plots

Poultry and cow manure was composted in concrete bins $3 \mathrm{~m}$ long, $50 \mathrm{~cm}$ wide and $40 \mathrm{~cm}$ deep. A total of 4 bins were used, of which two were used for poultry litter and 2 for cow litter. The different litters were stored in the bins and then closed with palm leaves to ensure a high temperature and allow water to enter (Figure 2). To produce organic fertiliser, composting was carried out for four weeks and the turning periods were on days 2,4 , 8 and 16 after storage in the bins. Watering was done as needed.

The fertilisers were applied individually (compost or NPK) or combined (compost + NPK) depending on the treatments. A crown-shaped opening was made in the upper part of each mound to receive the fertiliser. The fertiliser was covered with soil after application on the mound (Figure 3). The application was made three (3) months after planting.
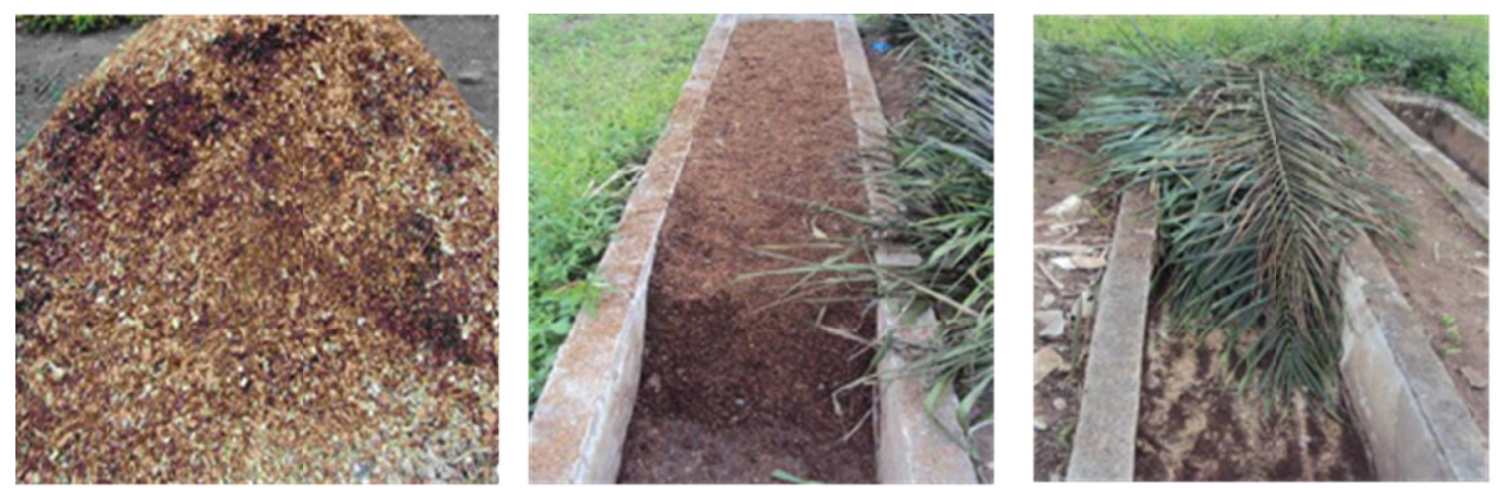

Figure 2. Different stages of composting poultry litter and cow dung

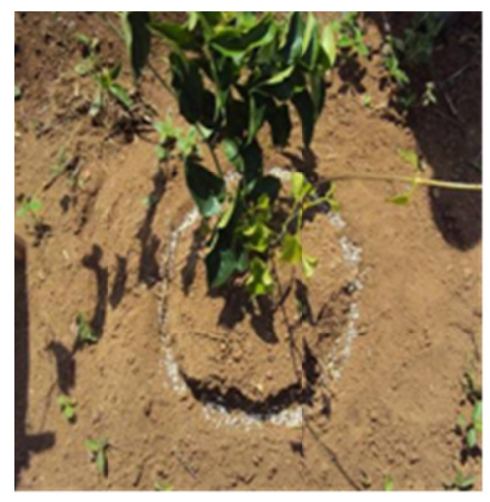

A: Mineral fertilisation

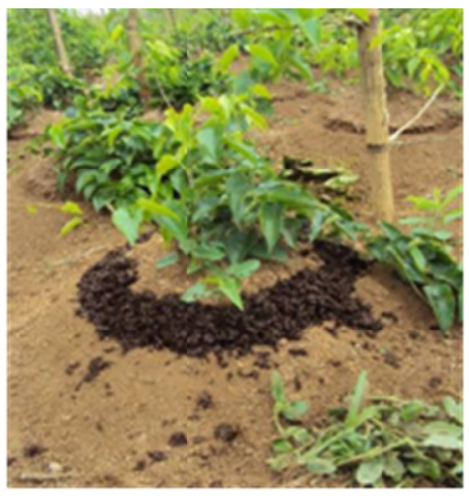

B: Organic Fertilisation

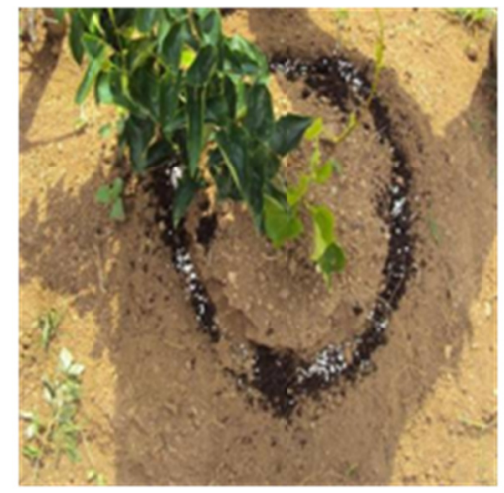

C: Organo-mineral fertilisation

Figure 3. Fertiliser application method

\subsubsection{Data Collected}

Three (3) parameters were measured during yam growth, three (3) to five (5) months after planting (during two (2) month after fertilisation). These are the stem elongation, the number of new branches and leaves emitted.

Stem's length was taken from the soil surface (mound) to the tip of the stem at three (3) and five (5) month. The difference between the two measurements gave the stem elongation. The number of branches and leaves emitted is obtained by counting each one that appears newly during the observation period. 
At harvest, the tubers' weight per mound, the number of tubers per mound and the dry matter content were noted. The tubers' weight per mound was determined using a $5 \mathrm{Kg} \times 1 \mathrm{~g}$ precision scale. The number of tubers per mound was determined by counting the total number of tubers per mound.

Concerning the dry matter content (DMC), after the harvest, samples were taken at three different levels from randomly selected tubers: the middle, distal and apical parts of the tuber. All these samples were then merged to obtain a composite sample per treatment and year. The resulting pieces were peeled, and a $200 \mathrm{~g}$ fraction was taken to give the fresh weight (FW) per sample. According to the treatment and year, these $200 \mathrm{~g}$ fractions were then cut into small strips and placed in aluminium foil. The aluminium foil containing these yam strips was put in an oven at $100{ }^{\circ} \mathrm{C}$ for 24 hours. The dry and cooled samples were weighed to determine their dry weight (DW). The dry matter content was determined according to the following formula:

$$
\mathrm{DMC}(\%)=\frac{\mathrm{FW}}{\mathrm{DW}} \times 100
$$

\subsubsection{Data Processing}

The observations and measurements were analysed using SPSS version 20 software, and an analysis of variance (ANOVA) was first performed. Themeans were then separated by the Turkey test at the $5 \%$ threshold when the effects were significant. The normality of the data and the homogeneity of the variances were checked beforehand using the test of Kolmogorov-Smirnov and Shapiro-Wilk.

\section{Results}

\subsection{Effects of Organo-mineral Fertilisation on Growth Parameters}

Table 3 shows the results of the analysis of variance for mean stem length increasing, number of branches and leaves emitted for each treatment from three to five months after planting. This analysis shows a significant difference in mean stem elongation $(\mathrm{P} \leq 0.05)$. The treatments CM 20 t/ha, NPK $0+\mathrm{PM} 0+\mathrm{CM} 0$ and NPK $100 \mathrm{~kg} / \mathrm{ha}+\mathrm{CM} 10 \mathrm{t} / \mathrm{ha}$ had the highest increasing in stem lengths (respectively $80.21,78.68$ and $76.06 \mathrm{~cm}$ ). NPK $50 \mathrm{~kg} / \mathrm{ha}+$ CM $15 \mathrm{t} / \mathrm{ha}(65.95 \mathrm{~cm})$, NPK $50 \mathrm{~kg} / \mathrm{ha}+$ PM $15 \mathrm{t} / \mathrm{ha}(64.93 \mathrm{~cm})$ and PM $20 \mathrm{t} / \mathrm{ha}(59.29 \mathrm{~cm})$ were ranked in second position for this parameter. Lowest increase in stem lengths were observed with NPK $200 \mathrm{~kg} / \mathrm{ha}(40.15 \mathrm{~cm})$, NPK $100 \mathrm{~kg} / \mathrm{ha}+$ PM 10 t/ha $(39.22 \mathrm{~cm})$ and NPK $300 \mathrm{~kg} / \mathrm{ha}(36.30 \mathrm{~cm})$.

There is also a significant difference between the different treatments applied $(\mathrm{P}=0.00)$ in terms of the number of branches produced. The highest numbers of branches $(5 \pm 1)$ were recorded with CM 20 t/ha and NPK 100 $\mathrm{kg} / \mathrm{ha}+\mathrm{CM} 10 \mathrm{t} / \mathrm{ha}$ followed by PM $20 \mathrm{t} / \mathrm{ha}(4 \pm 1)$. NPK $300 \mathrm{~kg} / \mathrm{ha}$, NPK $200 \mathrm{~kg} / \mathrm{ha}+\mathrm{CM} 5 \mathrm{t} / \mathrm{ha}$ and NPK 200 $\mathrm{kg} / \mathrm{ha}+$ PM $5 \mathrm{t} / \mathrm{ha}$ had the lowest number of branches $(1 \pm 1)$.

The number of leaves produced also shows a significant difference $(\mathrm{P}=0.02)$ between the different treatments used. CM $20 \mathrm{t} / \mathrm{ha}$ and NPK $0+$ PM $0+$ CM 0 gave the highest number of leaves produced (20 and 18). They were followed by NPK $100 \mathrm{~kg} / \mathrm{ha}+\mathrm{CM} 10 \mathrm{t} / \mathrm{ha} \mathrm{(16),} \mathrm{NPK} 50 \mathrm{~kg} / \mathrm{ha}+\mathrm{CM} 15 \mathrm{t} / \mathrm{ha} \mathrm{(16)} \mathrm{and} \mathrm{PM} 20 \mathrm{t} / \mathrm{ha} \mathrm{(15).}$ The smallest number of emitted leaves (11) was recorded for NPK $300 \mathrm{~kg} / \mathrm{ha}$, NPK $200 \mathrm{~kg} / \mathrm{ha}, \mathrm{NPK} 200 \mathrm{~kg} / \mathrm{ha}+$ CM 5 t/ha and NPK $100 \mathrm{~kg} / \mathrm{ha}+\mathrm{PM} 10 \mathrm{t} / \mathrm{ha}$.

High doses of organic fertiliser (CM 20 t/ha and PM 20 t/ha) had a positive impact on growth parameters. However, the inverse effect was observed with high doses of mineral fertilisers (NPK $300 \mathrm{~kg} / \mathrm{ha}$ and NPK 200 $\mathrm{kg} / \mathrm{ha})$.

Organo-mineral fertilisers NPK $100 \mathrm{~kg} / \mathrm{ha}+\mathrm{CM} 10 \mathrm{t} / \mathrm{ha}$, NPK $50 \mathrm{~kg} / \mathrm{ha}+\mathrm{CM} 15 \mathrm{t} / \mathrm{ha}$ and NPK $50 \mathrm{~kg} / \mathrm{ha}+\mathrm{PM}$ $15 \mathrm{t} / \mathrm{ha}$ allowed good vegetative growth. Combinations of organic fertiliser (CM or PM) with $200 \mathrm{~kg} / \mathrm{ha}$ of NPK did not improve growth. 
Table 3. Effect of treatments on stem length increasing, number of branches and leaves emitted from three to five months after planting

\begin{tabular}{|c|c|c|c|}
\hline Treatments & Stem length increasing $(\mathrm{cm})$ & Number of branches produced & Number of leaves produced \\
\hline CM 15 t/ha & $50.36 \pm 46.60^{\text {cd }}$ & $2 \pm 1^{d}$ & $13 \pm 10^{\mathrm{c}}$ \\
\hline CM 20 t/ha & $80.21 \pm 75.06^{\mathrm{a}}$ & $5 \pm 1^{\text {a }}$ & $18 \pm 14^{\text {a }}$ \\
\hline PM 15 t/ha & $50.47 \pm 52.86^{\mathrm{cd}}$ & $3 \pm 1^{\mathrm{c}}$ & $13 \pm 11^{\mathrm{c}}$ \\
\hline PM 20 t/ha & $59.29 \pm 54.65^{\mathrm{bc}}$ & $4 \pm 1^{\mathrm{b}}$ & $15 \pm 12^{\mathrm{b}}$ \\
\hline NPK $0+$ PM $0+$ CM 0 & $78.68 \pm 54.60^{\mathrm{a}}$ & $2 \pm 1^{\mathrm{d}}$ & $20 \pm 14^{\mathrm{a}}$ \\
\hline NPK $50 \mathrm{~kg} / \mathrm{ha}+\mathrm{CM} 15 \mathrm{t} / \mathrm{ha}$ & $65.95 \pm 57.23^{\mathrm{b}}$ & $3 \pm 1^{\mathrm{c}}$ & $16 \pm 12^{b}$ \\
\hline NPK 50 kg/ha + PM 15 t/ha & $64.93 \pm 52.44^{\mathrm{b}}$ & $2 \pm 1^{\mathrm{d}}$ & $13 \pm 10^{\mathrm{c}}$ \\
\hline NPK $100 \mathrm{~kg} / \mathrm{ha}+\mathrm{CM} 10 \mathrm{t} / \mathrm{ha}$ & $76.06 \pm 69.92^{\mathrm{a}}$ & $5 \pm 1^{\text {a }}$ & $16 \pm 13^{b}$ \\
\hline NPK $100 \mathrm{~kg} / \mathrm{ha}+\mathrm{PM} 10 \mathrm{t} / \mathrm{ha}$ & $39.22 \pm 34.44 \mathrm{de}$ & $2 \pm 1^{\mathrm{d}}$ & $11 \pm 9^{c}$ \\
\hline NPK $200 \mathrm{~kg} / \mathrm{ha}$ & $40.15 \pm 44.54 \mathrm{de}$ & $2 \pm 1^{\mathrm{d}}$ & $11 \pm 9^{c}$ \\
\hline NPK $200 \mathrm{~kg} / \mathrm{ha}+\mathrm{CM} 5 \mathrm{t} / \mathrm{ha}$ & $48.83 \pm 33.95^{\mathrm{d}}$ & $1 \pm 1^{\mathrm{d}}$ & $11 \pm 9^{c}$ \\
\hline NPK 200 kg/ha + PM 5 t/ha & $55.93 \pm 44.33^{\mathrm{c}}$ & $1 \pm 1^{\mathrm{d}}$ & $13 \pm 10^{\mathrm{c}}$ \\
\hline NPK $300 \mathrm{~kg} / \mathrm{ha}$ & $36.30 \pm 24.03^{\mathrm{e}}$ & $1 \pm 1^{d}$ & $11 \pm 8^{c}$ \\
\hline Fcal & $3.904 *$ & $4.017 *$ & $3.071 *$ \\
\hline Pcal & 0.00 & 0.00 & 0.02 \\
\hline Pthéor & $\leq 0.05$ & $\leq 0.05$ & $\leq 0.05$ \\
\hline
\end{tabular}

Note. According to the Turkey test, ${ }^{*}$ Averages followed by the same letter in the same column are not significantly different at the Probability threshold of 0.05 .

$\mathrm{F}=$ Fisher's F (ANOVA), Prcal $=$ Calculated Probability, Pthéor $=$ Theoretical Probability, ${ }^{*}=$ significant.

\subsection{Effect of Organo-mineral Fertilisation on Yield Components}

\subsubsection{Influence of Treatments on the Weight and Number of Tubers}

Table 4 shows the tuber weights per mound (TWM), the yields of fresh tubers, the gain in yield and the number of tubers per mound (NTM) for the different treatments. Analysis of this table shows that there is a significant difference in the weight of tubers compared to the treatments $(\mathrm{P}=0.038)$. On the other hand, there is no significant difference in the number of tubers between treatments $(P=0.643)$. The treatment NPK $200 \mathrm{~kg} / \mathrm{ha}+$ CM 5 t/ha results in higher tuber weights $(1442.44 \pm 742.51)$. The lowest weight comes from the PM $20 \mathrm{t} / \mathrm{ha}$ plot (1083.58 \pm 679.03$)$. The yield expressed in $t / h$ reveals that the combination of mineral and organic fertiliser at the dose of NPK $200 \mathrm{~kg} / \mathrm{ha}+\mathrm{CM} 5 \mathrm{t} / \mathrm{ha}$ gives the highest yield of $14.42 \mathrm{t} / \mathrm{ha}$. It is followed respectively by the treatments CM 15 t/ha, PM 15 t/ha and NPK $200 \mathrm{~kg} / \mathrm{ha}+$ PM 5 t/ha with $13.59 \mathrm{t} / \mathrm{ha}, 13.5015 \mathrm{t} / \mathrm{ha}$ and 13.30 t/ha. The lowest yields were recorded by the treatments NPK 0+PM 0+CM $0(11.56 \mathrm{t} / \mathrm{ha}), \mathrm{NPK} 300 \mathrm{~kg} / \mathrm{ha}(11.29 \mathrm{t} / \mathrm{ha})$, NPK $100 \mathrm{~kg} / \mathrm{ha}+\mathrm{CM} 10 \mathrm{t} / \mathrm{ha}(11.25 \mathrm{t} / \mathrm{ha})$, NPK $100 \mathrm{~kg} / \mathrm{ha}+$ PM $10 \mathrm{t} / \mathrm{ha}(11.08 \mathrm{t} / \mathrm{ha})$, PM $20 \mathrm{t} / \mathrm{ha}(10.83 \mathrm{t} / \mathrm{ha})$.

The high dose of mineral fertiliser (NPK $300 \mathrm{~kg} / \mathrm{ha}$ ) gave a low yield similar to the unfertilized control (NPK $0+\mathrm{PM} 0+\mathrm{CM} 0)$. Organo-mineral fertilisation combining a small dose of organic fertiliser $(5 \mathrm{t} / \mathrm{ha})$ with a medium dose of mineral fertiliser (200 kg/ha) increased the tuber yield by 15 to $25 \%$. A similar result is observed on yields with medium-high dose of organic fertilisers (15 t/ha) for an increase of 17 to $18 \%$.. The high doses of organic fertiliser (CM 20 t/ha and PM 20 t/ha) did not significantly increase the tuber yield. 
Table 4. Effect of treatments on the weight and number of tubers per mound

\begin{tabular}{|c|c|c|c|c|}
\hline Treatments & TWM (g) & Yield (t/ha) & Gain in yield/control (\%) & NTM \\
\hline CM 15 t/ha & $1359.09 \pm 931.95^{\mathrm{a}}$ & 13.59 & 18 & $2 \pm 1^{\mathrm{a}}$ \\
\hline CM 20 t/ha & $1232.68 \pm 800.37^{\mathrm{ab}}$ & 12.32 & 7 & $2 \pm 1^{\text {a }}$ \\
\hline PM 15 t/ha & $1350.58 \pm 885.55^{\mathrm{a}}$ & 13.50 & 17 & $2 \pm 1^{\mathrm{a}}$ \\
\hline PM 20 t/ha & $1083.58 \pm 679.03^{b}$ & 10.83 & -6 & $2 \pm 1^{\text {a }}$ \\
\hline NPK $0+\mathrm{PM} 0+\mathrm{CM} 0$ & $1156.02 \pm 879.00^{\mathrm{b}}$ & 11.56 & 0 & $1 \pm 1^{\text {a }}$ \\
\hline NPK $100 \mathrm{~kg} / \mathrm{ha}+\mathrm{CM} 10 \mathrm{t} / \mathrm{ha}$ & $1125.93 \pm 696.46^{\mathrm{b}}$ & 11.25 & -3 & $2 \pm 1^{\mathrm{a}}$ \\
\hline NPK $100 \mathrm{~kg} / \mathrm{ha}+\mathrm{PM} 10 \mathrm{t} / \mathrm{ha}$ & $1108.54 \pm 696.89^{b}$ & 11.08 & -4 & $2 \pm 1^{\mathrm{a}}$ \\
\hline NPK $200 \mathrm{~kg} / \mathrm{ha}$ & $1231.05 \pm 859.69^{a b}$ & 12.31 & 6 & $2 \pm 1^{\text {a }}$ \\
\hline NPK $200 \mathrm{~kg} / \mathrm{ha}+\mathrm{CM} 5 \mathrm{t} / \mathrm{ha}$ & $1442.44 \pm 742.51^{\mathrm{a}}$ & 14.42 & 25 & $2 \pm 1^{\mathrm{a}}$ \\
\hline NPK $200 \mathrm{~kg} / \mathrm{ha}+\mathrm{PM} 5 \mathrm{t} / \mathrm{ha}$ & $1330.72 \pm 892.88^{\mathrm{a}}$ & 13.30 & 15 & $2 \pm 1^{\mathrm{a}}$ \\
\hline NPK $300 \mathrm{~kg} / \mathrm{ha}$ & $1129.31 \pm 785.12^{\mathrm{b}}$ & 11.29 & -2 & $2 \pm 1^{\text {a }}$ \\
\hline NPK $50 \mathrm{~kg} / \mathrm{ha}+\mathrm{CM} 15 \mathrm{t} / \mathrm{ha}$ & $1241.86 \pm 841.457^{\mathrm{ab}}$ & 12.41 & 7 & $2 \pm 1^{\mathrm{a}}$ \\
\hline NPK $50 \mathrm{~kg} / \mathrm{ha}+\mathrm{PM} 15 \mathrm{t} / \mathrm{ha}$ & $1226.67 \pm 708.34^{\mathrm{ab}}$ & 12.26 & 6 & $2 \pm 1^{\mathrm{a}}$ \\
\hline Fcal & $2.053 *$ & & & $0.755 \mathrm{~ns}$ \\
\hline Pcal & 0.038 & & & 0.643 \\
\hline Pthéor & $\leq 0.05$ & & & $\geq 0.05$ \\
\hline
\end{tabular}

Note. According to the Turkey test, means followed by the same letter in the same column are not significantly different at the Probability threshold of 0.05 .

$\mathrm{F}=$ File F (ANOVA), Prcal $=$ Calculated Probability, Pthéor $=$ Theoretical Probability, ${ }^{*}=$ significant, $\mathrm{ns}=$ not significant.

TWM: tuber weight per mound, NTM: number of tubers per mound.

3.2.2 Effect of the Year of Cultivation on Average Weight, the Average Number of Tubers, and Dry Matter Content

The results in Table 5 show the effect of the cropping year on yield parameters. In general, the cropping year has a significant impact on the various performance components. The first season (year 1) had a better effect on these parameters than the following season, except for the number of tubers harvested. Interactions between fertilisation and crop year were only significant on the average weight of tubers harvested per mound.

Table 5. Effect of fertilisation and year of cultivation on yield parameters

\begin{tabular}{|c|c|c|c|}
\hline Factors & TWM (g) & NTM & DMC (\%) \\
\hline Year 1 & $1531 \mathrm{a}$ & $1.558 \mathrm{a}$ & $33.71 \mathrm{a}$ \\
\hline Year 2 & $923 \mathrm{~b}$ & $1.739 \mathrm{~b}$ & $31.65 \mathrm{~b}$ \\
\hline $\mathrm{NPK} 0+\mathrm{PM} 0+\mathrm{CM} 0$ & 1151 & 1.5 & 33.79 \\
\hline NPK $200 \mathrm{~kg} / \mathrm{ha}$ & 1234 & 1.696 & 33.52 \\
\hline NPK $300 \mathrm{~kg} / \mathrm{ha}$ & 1127 & 1.656 & 33.0 \\
\hline NPK $200 \mathrm{~kg} / \mathrm{ha}+\mathrm{CM} 5 \mathrm{t} / \mathrm{ha}$ & 1440 & 1.683 & 31.26 \\
\hline NPK $100 \mathrm{~kg} / \mathrm{ha}+\mathrm{CM} 10 \mathrm{t} / \mathrm{ha}$ & 1129 & 1.695 & 32.66 \\
\hline NPK 50 kg/ha + CM 15 t/ha & 1247 & 1.635 & 32.83 \\
\hline NPK $200 \mathrm{~kg} / \mathrm{ha}+\mathrm{PM} 5 \mathrm{t} / \mathrm{ha}$ & 1326 & 1.536 & 33.23 \\
\hline NPK $100 \mathrm{~kg} / \mathrm{ha}+\mathrm{PM} 10 \mathrm{t} / \mathrm{ha}$ & 1110 & 1.724 & 31.01 \\
\hline NPK 50 kg/ha + PM 15 t/ha & 1235 & 1.594 & 32.58 \\
\hline CM $20 \mathrm{t} / \mathrm{ha}$ & 1225 & 1.702 & 33.48 \\
\hline CM 15 t/ha & 1359 & 1.661 & 33.22 \\
\hline PM 15 t/ha & 1347 & 1.768 & 30.82 \\
\hline PM 20 t/ha & 1090 & 1.537 & 33.44 \\
\hline Year & $\mathbf{H S}$ & $\mathbf{H S}$ & $\mathbf{H S}$ \\
\hline Fertilisation & $\mathbf{S}$ & NS & NS \\
\hline Fertilisation $\times$ Year & $\mathbf{S}$ & NS & NS \\
\hline
\end{tabular}

Note. HS: Highly significant; S: Significant; NS: Not significant. 


\subsubsection{Effect of Interaction of Fertiliser and Cropping Year on Yield Parameters}

Comparing the different yield parameters according to treatments and cropping years from the analysis of variance (Table 6) shows a significant difference in tuber weight $(\mathrm{P}=0.03)$. In both the first and second year, the NPK treatment of $200 \mathrm{~kg} / \mathrm{ha}+\mathrm{CM} 5 \mathrm{t} / \mathrm{ha}$ resulted in the largest tubers, respectively $1715.91 \pm 658.96 \mathrm{~g}$ and $1155.95 \pm 723 \mathrm{~g}$. The combination NPK $100 \mathrm{~kg} / \mathrm{ha}+\mathrm{PM} 10 \mathrm{t} / \mathrm{ha}$ and the PM $20 \mathrm{t} / \mathrm{ha}$ treatment gave the lowest yields (1338.37 \pm 800.36 and $1338.57 \pm 712.87)$. The comparison of tuber weight in the two successive years shows that, in general, there is a reduction in tuber weight from the first year to the second year. The number of tubers $(\mathrm{P} \geq 0.05)$ shows that there are no significant differences between the treatments and the two crop cycles.

Table 6. Comparison of the weight and average number of tubers according to treatments and years of cultivation

\begin{tabular}{|c|c|c|c|c|}
\hline \multirow{2}{*}{ Treatments } & \multicolumn{2}{|c|}{ TWM (g) } & \multicolumn{2}{|c|}{ NTM } \\
\hline & Year 1 & Year 2 & Year 1 & Year 2 \\
\hline CM 15 t/ha & $1702.27 \pm 1040.12^{\mathrm{a}}$ & $1015.91 \pm 659.08^{\mathrm{a}}$ & $1 \pm 1^{\mathrm{a}}$ & $2 \pm 1^{\mathrm{a}}$ \\
\hline CM 20 t/ha & $1442.56 \pm 866.49^{b}$ & $1001.28 \pm 656.39^{\mathrm{a}}$ & $2 \pm 1^{\mathrm{a}}$ & $1 \pm 1^{\mathrm{a}}$ \\
\hline PM 15 t/ha & $1660.47 \pm 897.58^{\mathrm{a}}$ & $1040.70 \pm 764.71^{\mathrm{a}}$ & $3 \pm 1^{\mathrm{a}}$ & $3 \pm 1^{\mathrm{a}}$ \\
\hline PM 20 t/ha & $1338.57 \pm 712.87^{\mathrm{bc}}$ & $808.97 \pm 522.62^{b}$ & $1 \pm 1^{\mathrm{a}}$ & $1 \pm 1^{\mathrm{a}}$ \\
\hline $\mathrm{NPK} 0+\mathrm{PM} 0+\mathrm{CM} 0$ & $1419.77 \pm 1018.00^{b}$ & $872.50 \pm 591.06^{\mathrm{b}}$ & $1 \pm 1^{\mathrm{a}}$ & $1 \pm 1^{\mathrm{a}}$ \\
\hline NPK $100 \mathrm{~kg} / \mathrm{ha}+\mathrm{CM} 10 \mathrm{t} / \mathrm{ha}$ & $1374.39 \pm 746.33^{\mathrm{bc}}$ & $871.25 \pm 540.64^{b}$ & $2 \pm 1^{\mathrm{a}}$ & $1 \pm 1^{\mathrm{a}}$ \\
\hline NPK $100 \mathrm{~kg} / \mathrm{ha}+\mathrm{PM} 10 \mathrm{t} / \mathrm{ha}$ & $1338.37 \pm 800.36^{\mathrm{bc}}$ & $855.13 \pm 448.94^{\mathrm{a}}$ & $1 \pm 1^{\mathrm{a}}$ & $1 \pm 1^{\mathrm{a}}$ \\
\hline NPK $200 \mathrm{~kg} / \mathrm{ha}$ & $1682.27 \pm 845.48^{\mathrm{a}}$ & $758.33 \pm 578.88^{\mathrm{bc}}$ & $1 \pm 1^{\mathrm{a}}$ & $2 \pm 1^{\mathrm{a}}$ \\
\hline NPK $200 \mathrm{~kg} / \mathrm{ha}+\mathrm{CM} 5 \mathrm{t} / \mathrm{ha}$ & $1715.91 \pm 658.96^{\mathrm{a}}$ & $1155.95 \pm 723.32^{\mathrm{a}}$ & $1 \pm 1^{\mathrm{a}}$ & $1 \pm 1^{\mathrm{a}}$ \\
\hline NPK $200 \mathrm{~kg} / \mathrm{ha}+\mathrm{PM} 5 \mathrm{t} / \mathrm{ha}$ & $1646.51 \pm 950.77^{\mathrm{a}}$ & $991.25 \pm 688.91^{\mathrm{a}}$ & $1 \pm 1^{\mathrm{a}}$ & $1 \pm 1^{\mathrm{a}}$ \\
\hline NPK 300 kg/ha & $1478.89 \pm 764.36^{\mathrm{b}}$ & $754.76 \pm 623.01^{\mathrm{bc}}$ & $2 \pm 1^{\mathrm{a}}$ & $2 \pm 1^{\mathrm{a}}$ \\
\hline NPK $50 \mathrm{~kg} / \mathrm{ha}+\mathrm{CM} 15 \mathrm{t} / \mathrm{ha}$ & $1630.23 \pm 909.81^{\mathrm{a}}$ & $853.49 \pm 544.38^{b}$ & $1 \pm 1^{\mathrm{a}}$ & $1 \pm 1^{\mathrm{a}}$ \\
\hline NPK $50 \mathrm{~kg} / \mathrm{ha}+\mathrm{PM} 15 \mathrm{t} / \mathrm{ha}$ & $1421.19 \pm 748.36^{\mathrm{b}}$ & $1032.14 \pm 614.93^{\mathrm{a}}$ & $1 \pm 1^{\mathrm{a}}$ & $1 \pm 1^{\mathrm{a}}$ \\
\hline Fcal & $2.05 *$ & & $0.755 \mathrm{~ns}$ & \\
\hline Pcal & 0.03 & & 0.643 & \\
\hline Ptheor & $\leq 0.05$ & & $\geq 0.05$ & \\
\hline
\end{tabular}

Note. According to the Turkey test, means followed by the same letter in the same column are not significantly different at the Probability threshold of 0.05 .

\section{Discussion}

In terms of growth parameters, a very high/mineral fertiliser (NPK 15-15-15, $300 \mathrm{~kg} / \mathrm{ha}$ ) dose does not promote vegetative growth. According to Kimuni et al. (2014), any fertiliser added, the coefficient of fertilisers' effectiveness for different treatments decreases with increasing doses. These results show the interest and the need to use low doses of mineral fertilisers because high doses do not give good yields. On the other hand, the growth of krenglè yam is strongly favoured by the high doses of organic fertilisers. Organic matter plays an important role in the soil, thus promoting the growth of microorganisms which induce an activation of the solubilization of nutrients. Nutrients made sufficiently available and in large quantities over time in the soil are efficiently utilized by crop plants (Ojetayo et al., 2011). Likewise, the combination of mineral fertiliser with organic fertiliser has a good effect on vegetative growth. Indeed, yams also need balanced fertilisation during the vegetative phase. Suja (2005) proved that the additional inputs of nitrogen and phosphorus increases the leaf area index, the speed of vegetative development, the rate of net assimilation, and consequently, the yields of tubers in D. rotundata. According to Buresh et al. (1997) and Palm et al. (1997), it is generally accepted that organic and mineral fertilisers are necessary to increase agricultural production in West Africa. The plant absorbs the two complement each other and the mineral elements.

In contrast, the organic elements constitute reserves for the plant that it can draw on as it goes. The combination of organic and mineral fertilisation would positively influence growth. It would improve the soil structure, prevent its impoverishment and maintain its fertility (Giller et al., 1998).

Regarding the effects of mineral, organic, and organo-mineral fertilisation on yam's tuber yield, organo-mineral fertilisation induced an increase in tuber yields from 15 to $25 \%$. It is the same for organic fertilisation and 
mineral fertilisation at a medium-high dose (CM $15 \mathrm{t} / \mathrm{ha}$, PM $15 \mathrm{t} / \mathrm{ha}$ and NPK $200 \mathrm{~kg} / \mathrm{ha}$ ) with an increase in yield of 17 to $18 \%$. These observations suggest that the application of different manures contributed to the increase in tuber production. The quantity, the period and the technic of the fertiliser application allowed a good mineral nutrition of the plants, thus inducing their good aerial development and therefore a good photosynthetic activity. This also led to the leaves' production and the transfer to the underground parts of a greater quantity of nutrients. This could, therefore, explain the production of large tubers. The mean yields obtained vary between $10.83 \mathrm{t} / \mathrm{ha}$ and $14.42 \mathrm{t} / \mathrm{ha}$. They are far superior to those of Ettien et al. (2003) during the evaluation of new varieties of yam and N'Goran et al. (2007) in the bibliographic review on the management of the fertility of soils cultivated with yam who noted that, in Côte d'Ivoire, the standard yield varies between 8 and $12 \mathrm{t} / \mathrm{ha}$, even if according to FAO (1999), the yam potential is around $65 \mathrm{t} / \mathrm{ha}$.

Several authors have observed in their work an influence of mineral fertilisation on yam yield. Godo's (1990) work has shown that the yam responds better to organo-mineral manure than to strictly mineral manure. Likewise, Diby et al. (2009), Ettien et al. (2009), Diby et al. (2011), all observed a positive effect of mineral fertilisation on yam yield. In a study of the response of local varieties (Krenglè, Djaté, Kangba and Suidié) to mineral manure in the savannah zone of Côte d'Ivoire, Ettien (2004) tested three doses of fertiliser: T0 (control), T1 (120N 38P 103K), T2 (150N 49P 130K). The highest yield was recorded with the T1 rate for each variety. Soro et al. (2003), worked on four local varieties (Bètè bètè, Gnan, Krenglè and Wacrou) with three levels of fertiliser. They showed that the doses of T1 $(602565 \mathrm{Kg} / \mathrm{ha}$ of NPK) and T2 (2 times T1) are the basis of an increase in yield and the leaves' nitrogen content.

The method and timing of fertiliser application could also have induced optimal fertiliser used by plants. Indeed, the yam root system develops superficially (Hgaza et al., 2011). The method consists of a localized application of the fertiliser on the mound. In addition, the application of fertilisers took place at a rather decisive period of the yam development cycle. According to Craufurd et al. (2000), particularly, the phase of maximum plant growth is.a sensitive period in the cycle of this culture. Soro et al. (2003), and Agbede et al. (2013), observed a beneficial effect of organic amendments on yam production. Organic matter acts by promoting the absorption by the plant of the mineral elements provided, in particular nitrogen, and consequently increases the efficiency of the use of these fertilisers (Vanlauwe et al., 2010). Although according to Chabalier (1982), the burying of organic matter does not affect tuber yields, Melteras et al. (2008) have shown that it intervenes by improving the soil's physical properties, which determine its capacity to retain water and mineral elements.

Yields vary from year to year. According to Maliki (2006) and Floquet et al. (2012), yam can be grown for two successive growing seasons on the same soil. However, in this case, greater difficulties of emergence can be observed. Also, this difference could be due to environmental constraints such as rainfall, humidity and temperature. Since yams are rainfed, climatic hazards, particularly the different rainfall from one year to another, can greatly reduce yields. These results are consistent with Sinsin and Kampmann (2010) work, which showed that it is the decrease in the quantity of water as the temperature increases, coupled with a decrease in the relative humidity of the water air, which affect plant growth. Ghosh et al. (1988), and Ike and Inoni (2006) similarly consider delayed rainfall as one of the main sources of decline in yam production. This work corroborates Dansi et al. (2013) and Ehounou (2014), who showed the importance of water requirements for yam cultivation, especially after germination of the crop, then between the fourteenth and twentieth week of growth.

The dry matter content varies slightly depending on the treatments. It is around $33 \%$ on average. This high dry matter rate could be explained by the fact that in practice, the harvest of the yam takes place at the complete senescence of the foliage; tuberization continues after this phenomenon and can induce an additional production of dry matter, nearly $40 \%$ of the total dry weight of the tuber harvested. Our results are similar to those of Kouame et al. (2020) when evaluating the yield and dry matter content of seven (7) varieties of sweet potato (Ipomoea Batatas (L.), Lam., 1793) in the region of Bouake, Côte d'Ivoire.

\section{Conclusion}

This work's objective was to study the effect of mineral, organic and organo-mineral fertilisation on the agronomic parameters of the yam variety Krenglè of $(D$. rotundata $)$.

At the end of our study, it emerges that, whether it is mineral, organic or organo-mineral fertilisation, it has an effect on the agronomic parameters of Krenglè.

High dose mineral fertilisation (NPK 15-15-15, $300 \mathrm{~kg} / \mathrm{ha}$ ) negatively influenced the growth and yield parameters of krenglè yam. 
High doses of organic fertilisers (Cow manure (CM) $20 \mathrm{t} /$ ha and poultry manure (PM) $20 \mathrm{t} / \mathrm{ha}$ ) have a positive effect on vegetative growth. On the other hand, it was the medium-high doses of organic fertiliser (CM $15 \mathrm{t} / \mathrm{ha}$ and PM $15 \mathrm{t} / \mathrm{ha}$ ) that allowed an increase in tuber yield from 17 to $18 \%$.

Organo-mineral fertilisation has given fairly satisfactory results on the growth of Krenglè yam. Regarding yield, organo-mineral fertilisation combining a small dose of organic fertiliser $(5 \mathrm{t} / \mathrm{ha})$ with a medium dose of mineral fertiliser (200 kg/ha) increased the tuber yield by 15 to $25 \%$.

Finally, the combinations of doses that can be recommended for the cultivation of Krengle are as follows: 200 $\mathrm{kg} /$ ha of NPK $15-15-15$ associated with $5 \mathrm{t} /$ ha of poultry or cow manure.

\section{References}

Agbede, T. M., Adekiya, A. O., \& Ogeh, J. S. (2013). Effect of organic fertilizers on yam productivity and some soil properties of a nutrient-depleted tropical Alfisol. Archives of Agronomy and Soil Science, 59(6), 803-822. https://doi.org/10.1080/03650340.2012.683423

Akassimadou, E. F., \& Yao-Kouamé, A. (2014). Caractéristiques morpho-pédologiques et potentiels d'un sol de bas-fond secondaire développé sur granito-gneiss en région de savane guinéenne (Centre de la Côte d'Ivoire). Journal of Applied Biosciences, 79, 6968-6982. https://doi.org/10.4314/jab.v79i1.17

Alabi, T. R., Adebola, P. O., Asfaw, A., De Koeyer, D., Lopez-Montes, A., \& Asiedu, R. (2019). Spatial Multivariate Cluster Analysis for Defining Target Population of Environments in West Africa for Yam Breeding. International Journal of Applied Geospatial Research, 10(3), 1-30. https://doi.org/10.4018/ ijagr.2019070104

Allogni, W. N., Coulibaly, O., Djade, M. K., Hounkponou, S., \& Cornet, D. (2006). Impact de la mécanisation de la transformation des tubercules d'igname et de racines de manioc en cossettes sur les moyens d'existence durables des ménages en Afrique de l'ouest: Cas du Bénin et du Togo. Bulletin de la Recherche Agronomique du Bénin, 52, 32-46.

Allouko, J. R. (2011). Etude du prégrossissement d'Oreochromisniloticus en étang de rizipisciculture (p. 50). Mémoire de fin d'étude de Diplôme d'Agronmie Approfondie, Institut National Félix Houphouët Boigny, Yamoussoukro, Côte d'Ivoire.

Asiedu, R. (2003). Yam in West Africa: Production and collaborative research. Agronomie Africaine, 4(SP), 173-176. Retrieved from https://hdl.handle.net/20.500.12478/6656

Asiedu, R., \& Sartie, A. (2010). Crops that feed the world 1. Yams: Yams for income and food security. Food Security, 2(4), 305-315. https://doi.org/10.1007/s12571-010-0085-0

Baize, D. (2004). Petit lexique de pédologie (p. 271). INRA Editions.

Baize, D., \& Jabiol, B. (1995). Guide pour la description des sols (p. 375). INRA Editions.

Brou, Y. T., Akindès, F., \& Bigot, S. (2005). La variabilité climatique en Côte d'Ivoire: Entre perceptions sociales et réponses agricoles. Cah. Agric., 14(6), 533-540. https://doi.org/10.13140/2.1.5174.3368

Buresh, I. J., Sanchez, P. A., \& Calhoun, F. (1997). Replenishing soil fertility in Africa: SSSA Special Publication 51, Soil Science Society of America (p. 264). American Society of Agronomy Madison, Wisconsin, USA. https://doi.org/10.2136/sssaspecpub51

Carsky, R. J., Wolo, N., Manyong, V. M., Tian, G., \& Asiedu, R. (1998). Nutrient Balance Modelling for Design of Sustainable Yam Cropping Systems (p. 14). Cotonou, Benin: ISTRC-AB.

Chabalier, P. F. (1982). Fertilisation chimique et organique. Rapport analytique (p. 28). IDESSA/DCV, Division d'Agronomie.

Chukwu, G. O., \& Ikwelle, M. C. (2000). Yam: Threats to its sustainability in Nigeria. News NRCRI Uudike, 17(1), 1-7.

Cornet, D. (2015). Influence des premiers stades de croissance sur la variabilité du rendement parcellaire de deux espèces d'igname (Dioscorea spp.) cultivées en Afrique de l'Ouest (p. 174). Paris, France: L'Institut des Sciences et Industries du Vivant et de l'Environnement (AgroParisTech).

Cornet, D., Sierra, J., Tournebize, R., \& Ney, B. (2014). Yams (Dioscorea spp.) plant size hierarchy and yield variability: Emergence time is critical. European Journal of Agronomy, 55, 100-107. https://doi.org/ 10.1016/j.eja.2014.02.002. 
Craufurd, P. Q., Sumerfield, R. J., Asiedu, R., \& Vara Prasa, P. V. (2000). Dormancy in yams. Experimental Agriculture, 37, 147-181. https://doi.org/10.1017/S001447970100206X

Dansi, A., Dantsey-Barry, H., Agre, A. P., Dossou Aminon, I., Assogba, P., Loko, Y. L., ... Vodouhè, R. (2013). Production constraints and farmers' cultivar preference criteria of cultivated yams (Dioscorea cayenensis-D. rotundata complex) in Togo. International Journal of Applied Biology and Pharmaceutical Technology, 4(2), 191-199.

Diby, L. N., Crasky, R., Tie, T. B., \& Girardin, O. (2012). Understanding soil factors limiting the potential yield of yam (Dioscorea spp.). Retrieved from http://www.cropscience.org.au/icsc2004/poster/2/3/322_dibyl.htm

Diby, L. N., Hgaza, V. K., Tie, T. B., Assa, A., Carsky, R., Girardin, O., \& Frossard, E. (2009). Productivity of yams (Dioscorea spp.) as affected by soil fertility. Journal of Animal and Plant Sciences, 5(2), 494-506.

Diby, L. N., Hgaza, V. K., Tié, T. B., Crasky, R., Girardin, O., \& Assa, A. (2011). Mineral nutrient uptake and partitioning in Dioscorea alata and Dioscorea rotundata. Journal of Applied Biosciences, 38, 2531-2539.

Ehounou, J. N. (2014). Impact de la variabilité des saisons de pluies sur les besoins en eau de l'igname, du manioc et du maïs dans la région centre de la Côte d'Ivoire. Mémoire de Master 2 de Sciences de la Terre Option: Hydrogéologie (p. 110). UFR des Sciences de la Terre et des Ressources Minières, Département des Sciences et Techniques de l'Eau et du Génie de l'Environnement, Université Félix Houphouët-Boigny, Abidjan-Côte d'Ivoire.

Ettien, D. J. B. (2004). Intensification de la production d'igname (Dioscorea spp.) par la fertilisation minérale et l'identification de nouvelles variétés en zone forestière et savanicole de Côte d'Ivoire (p. 187, Thèse de Doctorat Unique en Sciences de la Terre, Option: Agro-Pédologie, Université de Cocody, Abidjan, Côte d'Ivoire).

Ettien, J. B., Tschannen, A. B., Nindjin, C., Asiedu, R., Assa, A., \& Girardin, O. (2003). Evaluation de nouvelles variétés de d'igname en Côte d'Ivoire : Bilan de trois années d'expérience avec des génotypes améliorés par l'IITA. Agronomie Africaine, 4(SP), 109-116.

Ettien, J. R., Koné, R., Kouadio, K. H., Kouadio, N. E., Yao-Kouamé, A., \& Girardin, O. (2009). Fertilisation minérale des ferralsols pour la production d'igname en zone de Savane Guinéenne de l'Afrique de l'Ouest : cas des variétés d'igname traditionnelle sur dystricferralsols du Centre de la Côte d'Ivoire. Journal of Applied Biosciences, 23, 1394-1402.

FAO. (1997). Report on the inter-center review of root and tuber crops research in the CGIAR (p. 115). Rome: Food and Agriculture Organization (FAO), Consultative Group on International Agricultural Research, Technical Advisory Committee (TAC).

FAO. (1999). Culture et utilisation de l'igname pour assurer pour assurer la sécurité alimentaire, texte de référence, 1999. Retrieved from http://www.fao.org

Faostat. (2019). Production: Crops. Food and Agriculture Organization of the United Nations. Retrieved from http://faostat.fao.org

Floquet, A. B., Maliki, R., Tossou, R. C., \& Tokpa, C. (2012). Évolution des systèmes de production de l'igname dans la zone soudano-guinéenne du Bénin. Cahiers Agricultures, 21(6), 427-437. https://doi.org/10.1684/ agr.2012.0597

Ghosh, C., \& Woolridge, J. R. (1988). An analysis of shareholder reaction to dividend cuts and omissions. Journal of Financial Research, 11(4), 281-294. https://doi.org/10.1111/j.1475-6803.1988.tb00089.x

Giller, E., Cadisch, G., \& Mugwira, L. M. (1998). Potential benefits from interaction between organic and inorganic nutrient sources. In S. R. Waddington (Ed.), Fertility Research for maize-based farming systems in Malawi and Zimbabwe (pp. 155-158).

Godo, G. (1990). Le rôle de la matière organique sur la fertilité des sols ferrallittiques. Proceedings $\mathrm{N}^{\mathrm{o}} 10$, IBSRAM.

Hgaza, V. K., Diby, L. N., Oberson, A., \& Tschannen, A. (2012). Nitrogen Use by Yam as Affected by Mineral Fertilizer Application. Agronomy Journal, 104(6), 1558. https://doi.org/10.2134/agronj2011.0387

Hgaza, V. K., Diby, L. N., Tié, T. B., Tschannen, A., Aké, S., Assa, A., \& Frossard, E. (2011). Growth and Distribution of roots of Dioscorea alata L. The Open Plant Science Journal, 5, 14-22. https://doi.org/ $10.2174 / 1874294701105010014$ 
Ike, P. C., \& Inoni, E. O. E. (2006). Determinants of yam production and economic efficiency among small-holder farmers in Southeastern Nigeria. J. Cent. Eur. Agric., 7, 337-342.

Kimuni, L. N., Mwali, M. K., Mulembo, T. M., Lwalaba, J. W. L., Kanyenga, L. A., Katombe, J. L., ... Longanza, B. L. (2014). Influence de la fertilisation a base des déchets humains recycles, des engrais minéraux et de leur combinaison sur le comportement de maïs. Journal of Applied Biosciences, 77, 6500-6508. https://doi.org/10.4314/jab.v77i0.2

Konan, J. (2017). Compétition entre bâti et agriculture dans la conquête des bas-fonds de la ville de Bouaké : le savoir-faire ou les actions stratégiques des citadins agriculteurs pour préserver les espaces agricoles. Vertigo-la Revue Électronique en Sciences de l'Environment. https://doi.org/10.4000/vertigo.18302

Kouame, N., Dibi, K. E. B., Essis, B. S., Toure, N. C., \& Ngbesso, M. F. D. P. (2020). Evaluation of the Yields and the Dry Matter Content of Seven (7) Sweet Potato Varieties (Ipomoea batatas (L), Lam., 1793) in the Bouake Region, Côte d'Ivoire. Scholars Journal of Agriculture and Veterinary Sciences, 7(1), 18-23. https://doi.org/10.36347/sjavs.2020.v07i01.004

Maliki, R. (2006). Yam based sedentary cropping system and sustainable natural resources management in the central part of the Benin: Participatory development, constraints, adoption and diffusion of technologies. (p. 172, M.Sc. Thesis, University of Abomey-Calavai, Abomey-Calavi, Benin).

Melteras, M., Lebot, V., Asher, C. J., \& O’Sullivan, J. N. (2008). Crop development and distribution jn lesser yam (Dioscorea esculenta) implications for fertilization. Experimental Agriculture, 44, 209-221. https://doi.org/10.1017/S0014479708006339

N'goran, K. E., Zohouri, P. G., Yoro, R. G., Kouakou, M. A., Assa, A., \& Asiedu, R. (2007). Revue bibliographique sur la gestion de la fertilité des sols cultives en igname en Côte d'Ivoire, Agronomie Africaine, 19(3), 281-288. https://doi.org/10.4314/aga.v19i3.1725

Ojetayo, A. E., Olaniyi, J. O., Akanbi, W. B., \& Olabiyi, T. I. (2011). Effect of fertilizer types on nutritional quality of two cabbage varieties before and after storage. Journal of Applied Biosciences, 48, 3322-3330.

Palm, C. A., Myers, R. J. K., \& Nandwa, S. M. (1997). Combined use of organic and inorganic nutrient sources for soil fertility maintenance and replenishment. In R. J. Buresh, P. A. Sanchez \& F. Calhoun (Eds.), Replenishing soil fertility in Africa (pp. 193-217). ASA, CCSA, SSSA Special Republication 51, Madison, WI, USA. https://doi.org/10.2136/sssaspecpub51.c8

Séka, K., Diallo, A. H., Kouassi, N. K., \& Aké, S. (2009). Incidence du Yam mosaic virus (YMV) et du Cucumbermosaic virus (CMV) sur des variétés de Dioscorea spp. Cultivées dans les régions de Bouaké et de Toumodi en Côte d'Ivoire. Int. J. Biol. Chem. Sci., 3(4), 694-703. https://doi.org/10.4314/ijbcs. v3i4.47179

Sinsin, B., \& Kampmann, D. (2010). Atlas de la biodiversité de l'Afrique de l'ouest, Tome I: Bénin (p. 676). Cotonou et frankfurt/Main, BIOTA.

Soro, D., Dao, D., Carsky, R., Asiedu, R., Tra, T. B., Assa, A., \& Girardin, O. (2003). Amélioration de la production de l'igname à travers la fertilisation minérale en zone savane de Côte d'Ivoire. Agronomie Africaine, 4, 39-46.

Suja, G. (2005). lmpact of nutrient management on biomass production and growth indices of white yam (Dioscorea rotundata Poir.) intercropped in a coconut plantation in South lodia. Tropical Agriculture, 82, 173-182.

Traoré, K., Sorho, F., Dramane, D. D., \& Sylla, M. (2013). Adventices hôtes alternatifs de virus en culture de Solanaceae en Côte d'Ivoire. Agro. Afric., 25(3), 231-237.

Vanlauwe, B., Bationo, A., Chianu, J., Gîller, K. K., Merckx, R., Mokwunye, V., ... Sanginga, P. L. N. (2010). Integrated soil fertility Management Operational definition and consequences for implementatioll and dissemination. Agricullure, 39(1), 1724-1736. https://doi.org/10.5367/000000010791169998

Yesso, P., Kone, D., \& Meyer, C. (1991). Reprise post-partum et cyclicité des vaches trypanotolérantes en fonction de la variation saisonnière en région centre Côte d'Ivoire (p. 22). IAEA sur l'Amélioration de la Productivité du Bétail Indigène Africain en Utilisant les Méthodes Radio-immunologiques et Apparentées. Réunion de Coordination FAO, Bouaké, IDESSA. 


\section{Copyrights}

Copyright for this article is retained by the author(s), with first publication rights granted to the journal.

This is an open-access article distributed under the terms and conditions of the Creative Commons Attribution license (http://creativecommons.org/licenses/by/4.0/). 